\title{
Histopathological and Histomorphometric Studies on the Effects of Olanzapine on Vas Deferens and Urinary Bladder: An Experimental Study in Albino Rats.
}

\author{
Waqar Akram', Masooma Syed', Nafis Ahmad Faruqi ${ }^{2}$ \\ ${ }^{1}$ Senior Resident, Department Of Anatomy, J.N.M.C, A.M.U, Aligarh, ${ }^{2}$ Professor, Department Of Anatomy, J.N.M.C, A.M.U, Aligarh.
}

\section{Abstract}

Introduction: Olanzapine an atypical anti-psychotic drug is widely used in a number of disorders like schizophrenia and bipolar disorder. Olanzipine shows affinity for a number of muscarinic, dopaminergic and histaminic receptors in the body due to which its effects can be seen on a number of organs in the body. The present study was conducted to see the adverse effects of the drug on the histology of urinary bladder and vas deference as data is not availabe on these organs. Subjects and Methods: Twelve male albino rats divided into equal number of experimental and control groups i.e. 6 rats each. Olanzapine was injected intraperitoneally in experimental rats at a dose of $4 \mathrm{mg} / \mathrm{kg}$ for 6 weeks daily. Results: Control group received same volume of normal saline, daily, intraperitoneally for the same period. Conclusion: Histopathological and histomorphometric changes conformed degeneration in urinary bladder \& vas deferens.

Keywords: Olanzapine, urinary bladder, vas deference, schizophrenia.

Corresponding Author: Dr. Masooma Syed Senior Resident, Department Of Anatomy, J.N.M.C, A.M.U, Aligarh.

Received: April 2019

Accepted: May 2019

\section{Introduction}

Olanzapine is a widely used atypical antipsychotic agent, approved by the U.S. Food and Drug Administration for bipolar disorder and schizophrenia. ${ }^{[1]}$

Olanzapine shows affinity for D2 receptors, muscarinic and alpha 1 receptors with lower affinity for alpha 2, 5-HT 1D and 5 -HT1A receptors. ${ }^{[2]}$ Such affinity poses danger to wide range of organs in the body.

Urogenital system has attracted special attention from most of the scientists because of its direct impact on fertility. Vera et. al. ${ }^{[3]}$ has thoroughly explored the effect of olanzapine on the function of urinary bladder. Soliman et. al. ${ }^{[4]}$ has done extensive study to show effects of olanzapine on testis. Nephrotoxic effects of chronically administered olanzapine in male rats were reported by Gulec et. al. ${ }^{[5]}$ The duct system received little attention although these form important functional component of urogenital system.

Detailed histopathological and histomorphometric studies on vas deferens and urinary bladder are lacking in literature. Such information is directly related to the affinity of drug to these organs which might throw light in finding the mechanism of action.

\section{Subjects and Methods}

12 male albino rats (Rattus Norwegicus) weighing around 180-200 gms were procured from the "Central Animal House" of Jawaharlal Nehru Medical College, Aligarh. The clearance for use of animals was obtained from "Animal Ethics Committee" of JNMC Aligarh.

The rats were divided into equal number of experimental and control groups i.e. 6 each. Ad-libitum water and standard pellet laboratory diet (Lipton India Limited) were provided.

Olanzapine (inj. Oleanz, Sun Pharmaceuticals, Mumbai, India) was injected intraperitoneally daily in experimental rats at a dose of $4 \mathrm{mg} / \mathrm{kg}$ for 6 weeks. Control group received same volume of normal saline, daily, intraperitoneally for the same period.

After proposed experimental duration of 6 weeks exposure, the animals of both the experimental and control groups were anaesthetized by giving injection Nembutol $30 \mathrm{mg}$ per $\mathrm{kg}$, intraperitoneally. Blood transfusion set was introduced into the left ventricle (apex).Karnovsky's fixative was infused till the body showed signs of fixation.

Scrotal sac was opened and epididymis was traced to identify and dissect the vas deferens. Pelvis was explored to identify and dissect out the urinary bladder. Tissue of 2-3 $\mathrm{mm}$ was procured from vas deferens and urinary bladder. $10 \mu \mathrm{m}$ thick sections of tissue were obtained by wax embedding technique. Hematoxylin and Eosin were used for 
staining. Slides were minutely observed in light microscope under different magnification to find out detailed histopathological features. Histomorphometry was done by using stage and ocular micrometers and resutls were analysed by using student's 't'-test.

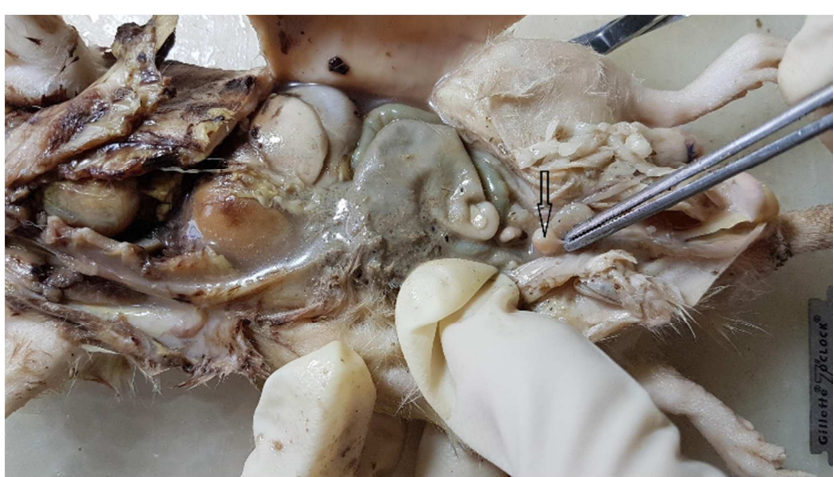

Figure 1: Dissection showing exposed urinary bladder (arrow) of male albino rat.

\section{Results}

The vas deferens of control rats showed fibromuscular wall made up of spindle shaped smooth muscles and wavy collagen fibers and a small lumen with mucosa thrown into folds lined by single layer of cuboidal cells. [Figure 2]

Experimental vas deferens showed subserosal dilated congested blood vessels and thickened edematous fibromuscular wall. The fibres were separated by spaces containing edema fluid. Cuboidal epithelium of mucosa showed focal degeneration and ulceration. Folded cuboidal epithelium lining the lumen showed degenerative changes as vacuolation and fragments of cytoplasm projecting in lumen from cell surface. A thrombus composed of fibrin threads, entangled red blood cells and white blood cells was seen in the lumen. [Figure 3]

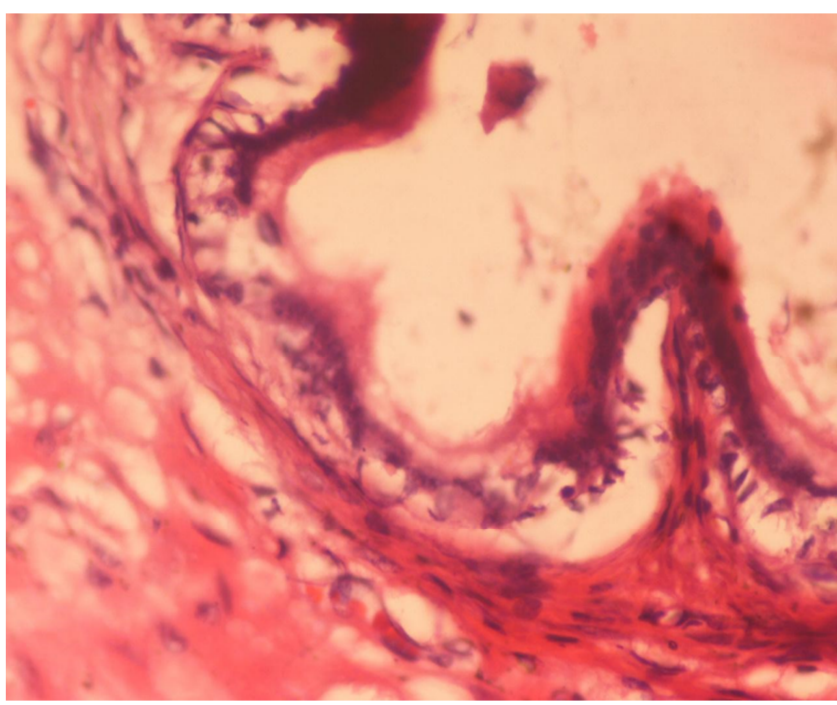

Figure 2: Photomicrograph of control vas deferens showing Fibromuscular wall made of spindle shaped smooth muscles and wavy collagen fibres. Mucosa shows folds and is lined by single layer of cuboidal cells. (H\&E Stain 40X)

The control urinary bladder showed outer thin fibrous serosa, muscular wall made up of two spiral layers of muscle and mucosa made of transitional epithelium, lamina propria and muscularis mucosa [Figure 4]. Transitional epithelium was made up of four layers of cells. Each surface umbrella cell covered 4-5 deeper cells. Lamina propria showed loose connective tissue. Mucosa was folded and lumen contained urine [Figure 6].

Experimental urinary bladder showed hypertrophic and edematous muscular wall. Muscle bundles were separated by spaces containing edema fluid. Mucosa was edematous with inflammatory cell infiltrate.

Nuclei were enlarged and edematous with margination of chromatin [Figure 7]. Lamina propria was edematous with dilated and congested capillaries and acute inflammatory cell infiltrate [Figure 5]. Mucosa showed indippings (Van Brunn's Nest) reaching muscle tissue and folds with lining of hyperplastic transitional epithelium and focal areas of thinning.

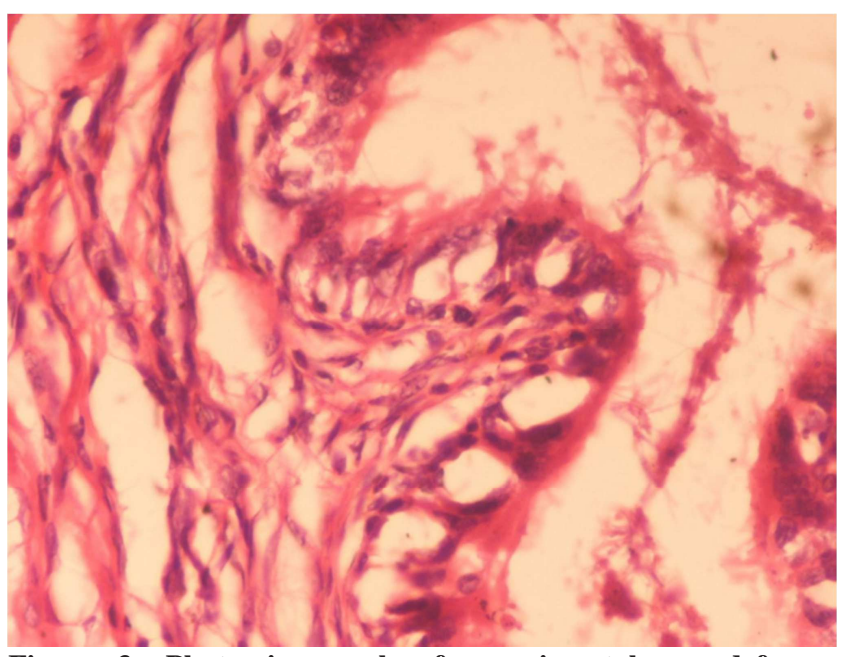

Figure 3: Photomicrograph of experimental vas deferens showing edema of muscle coat separating the fibres. Folded cuboidal epithelium lining the lumen shows degenerative changes as vacuolation and fragments of cytoplasm projecting in lumen from cell surface. A thrombus in lumen is composed of fibrin threads, entangled RBC's and WBC's. (H\&E, 40X)

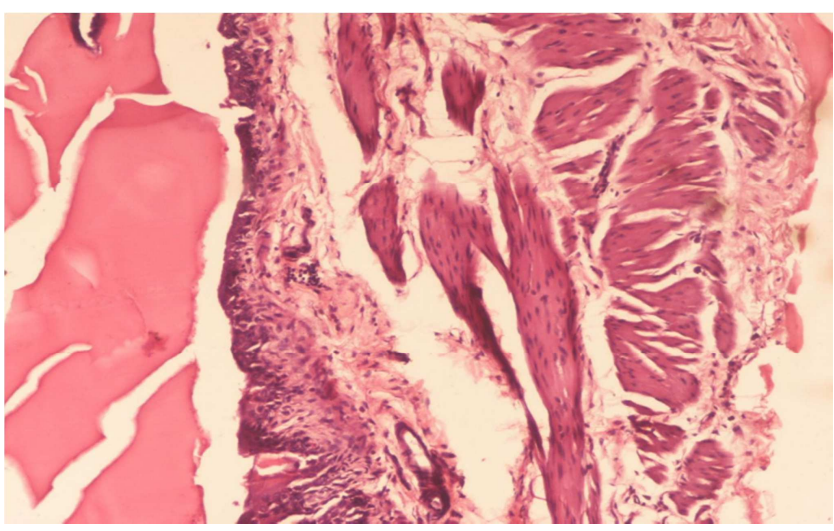

Figure 4: Photomicrograph of control urinary bladder showing outer thin fibrous serosa, two Spiral layers of smooth muscle in muscle coat. Mucosa is made up of transitional epithelium, lamina propria and muscularis mucosa. Lumen contains urine. (H\&E Stain 10X) 


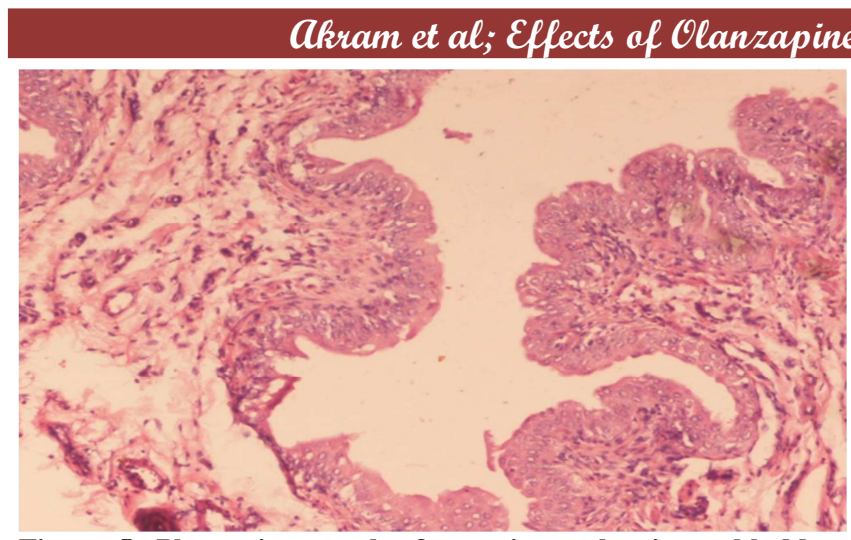

Figure 5: Photomicrograph of experimental urinary bladder: Mucosa is folded and lined by edematous transitional epithelium, which is $\mathbf{8}$ cell thick with focal ulceration.Lamina propria is edematous with dilated and congested capillaries and acute inflammatory cell infiltrate. (H\&E Stain 10X)

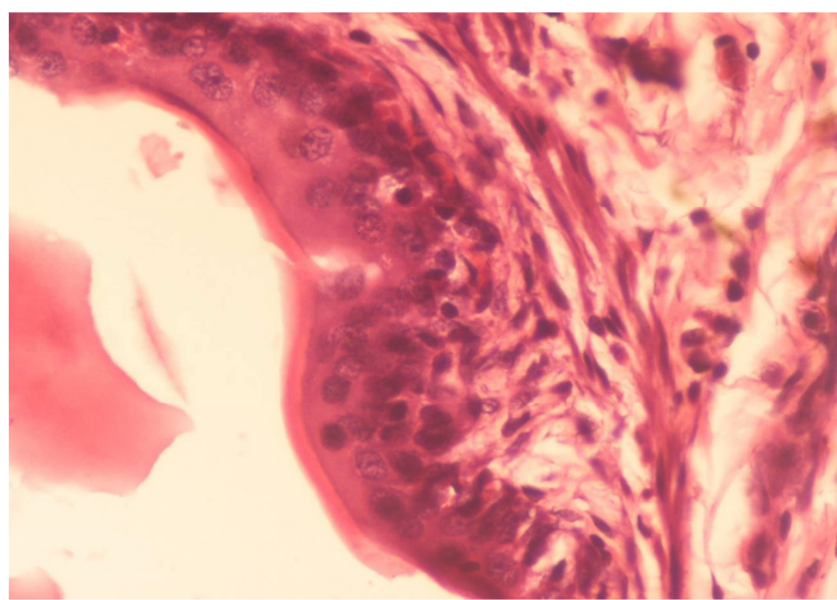

Figure 6: Photomicrograph of control urinary bladder: Mucosa shows transitional epithelium made of four layers of cells with basal nuclei perpendicular to basement membrane. More superficial cells are larger and polygonal. Each surface umbrella cell covers 4-5 deeper cells. Lamina propria shows loose connective tissue. A thin layer of spindle smooth muscle makes muscularis mucosa limiting the mucosa. Urine seen in lumen. (H\&E, 40X)

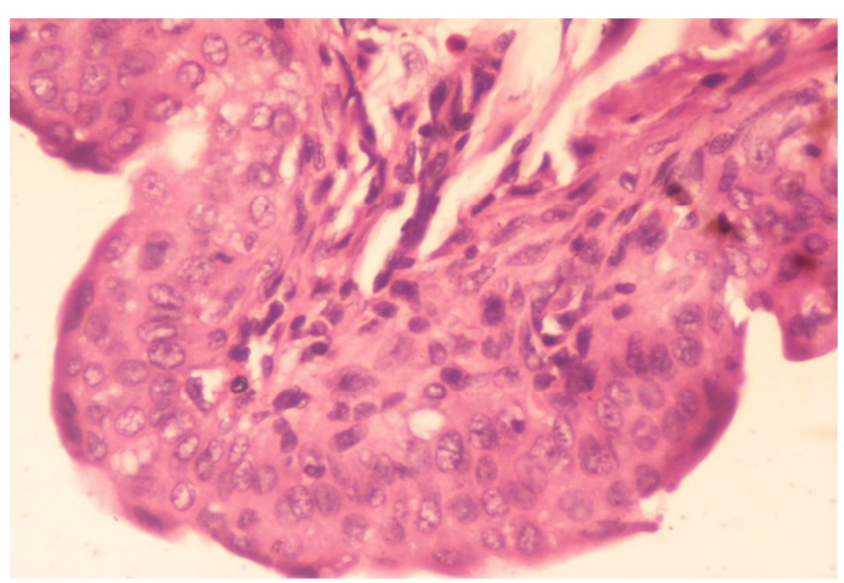

Figure 7: Photomicrograph of experimental urinary bladder: Transitional epithelium of mucosa shows 6-7 cells thick epithelium, epithelial cells are swollen with focal ulceration of umbrella cells. Lamina propria made of loose connective tissue is edematous with large number of acute inflammatory cells. (H\&E, 40X)

\section{Histomorphometric Findings}

Histomorphometric findings are given in Table 1. We found that the diameter of vas deferens lumen was increased from $250 \mu \mathrm{m}$ to $335.72 \mu \mathrm{m}$ and this increment was not significant, while the thickness of the wall was increased from 553.57 $\mu \mathrm{m}$ to $714.29 \mu \mathrm{m}$ and this increase was mildly significant $(\mathrm{p}<0.02)$.

In urinary bladder the thickness of the epithelium was increased from $42.857 \mu \mathrm{m}$ to $58.65 \mu \mathrm{m}$ and this enhancement was highly significant $(\mathrm{p}<0.001)$.

Table 1: Different measurements vas deferens and urinary bladder of control and experimental (olanzapine intoxicated) rats.

\begin{tabular}{|c|c|c|c|c|c|}
\hline Organs & $\begin{array}{l}\text { Diamete } \\
\text { r/ } \\
\text { Thicknes } \\
s(\mu \mathrm{m})\end{array}$ & $\begin{array}{l}\text { Control } \\
\text { Mean } \pm \\
\text { SD }\end{array}$ & $\begin{array}{l}\text { Experime } \\
\text { ntal } \\
\text { Mean } \quad \pm \\
\text { SD }\end{array}$ & $\begin{array}{l}\text { Per } \\
\text { cent } \\
\text { cha } \\
\text { nge }\end{array}$ & P Value \\
\hline \multirow[t]{2}{*}{$\begin{array}{l}\text { Vas } \\
\text { Deferens }\end{array}$} & Lumen & $\begin{array}{ll}250 & \pm \\
14.29 & \\
\end{array}$ & $\begin{array}{ll}335.72 & \pm \\
85.32 & \\
\end{array}$ & $\begin{array}{l}\uparrow 34 . \\
29\end{array}$ & $\begin{array}{l}\text { Insignifica } \\
\text { nt }\end{array}$ \\
\hline & Wall & $\begin{array}{ll}553.57 \quad \pm \\
57.59\end{array}$ & $\begin{array}{ll}714.29 & \pm \\
84.11 & \\
\end{array}$ & $\begin{array}{l}\uparrow 29 . \\
03\end{array}$ & $<0.02$ \\
\hline $\begin{array}{l}\text { Urinary } \\
\text { Bladder }\end{array}$ & $\begin{array}{l}\text { Epitheliu } \\
\mathrm{m}\end{array}$ & $\begin{array}{ll}42.857 \quad \pm \\
11.66\end{array}$ & $\begin{array}{ll}58.65 & \pm \\
10.54 & \end{array}$ & $\begin{array}{l}\text { १36. } \\
85\end{array}$ & $<0.001$ \\
\hline
\end{tabular}

\section{Discussion}

Marked degenerative changes were seen in experimental vas deferens in both cellular and intercellular regions. Cuboidal epithelium of mucosa showed focal degeneration and ulceration while excessive edema was noticed in the fibromuscular wall leading to its thickness which confirms our histomorphometric finding. Degenerative changes were also seen in the folded cuboidal epithelium in the form vacuolation and fragments of cytoplasm projecting in the lumen of cell surface. Reports on the effects of olanzapine on vas deferens were lacking in literature.

Detailed histopathological findings in urinary bladder were unique in the sense that no one has earlier reported specifically. Barring edema which was a toxic effect of olanzapine in all the organs under consideration, urinary bladder showed maximum degenerative changes in its mucosa especially epithelial lining. The latter was not only edematous with inflammatory cell infiltration but also showed hyperplasia as well as hypertrophy making it 8 cells thick. This increased the thickness of epithelium which was confirmed by histomorphometry. There was also focal ulceration of umbrella cells. Nuclei were enlarged with margination of chromatin. Most interestingly mucosa showed indippigs (Van Brunn's nest) reaching muscle tissue and folding with lining of hyperplastic transitional epithelium and focal areas of thinning. Available literature signified the functional aspects of urinary bladder after olanzapine intoxication. ${ }^{[3]}$

H1 histamine receptor are present in smooth muscles and endothelium. ${ }^{[6]}$ Presence of muscarinic receptors were well documented in smooth muscles, glands and endothelium. ${ }^{[7]}$ serotonergic receptors e.g. 5-HT 2A was also noticed in smooth muscles.

Aforesaid facts might be indicative of direct toxic effect of the drug on organs considered in our experiment. At the same time the damaging effects of olanzapine on organs 


\section{Akram et al; Effects of Olanzapine an Vas Deferens and Urinary Bladder}

under consideration may also be an indirect expression due to its direct effects on other organs of the body.

Formation of reactive oxygen species is induced by the use of olanzapine which might cause cellular damage and dysfunction. ${ }^{[8,9]}$ It has been proved that using antioxidant can reduce the metabolic changes in rats receiving olanzapine. ${ }^{[10]}$ Reactive oxygen species could also be generalized reason for changes in organs under consideration. Vascular factor might be another generalized reason for the degenerative changes. But this prediction needed further experimental studies for confirmation.

\section{Conclusion}

Olanzapine lead to histopathological and histomorphometric changes conforming degeneration in urinary bladder \& vas deferens. Edema was a generalized feature in both organs under consideration. Since olanzapine exhibits affinity for large number of receptors distributed among many organs in the body, the toxicity seemed to be due to both direct and indirect effects.

\section{References}

1. Mitchell M, Riesenberg R, Bari MA, et al. A double-blind, randomized trial to evaluate the pharmacokinetics and tolerability of 30 or $40 \mathrm{mg} / \mathrm{d}$ oral olanzapine relative to $20 \mathrm{mg} / \mathrm{d}$ oral olanzapine in stable psychiatric subjects. Clin Ther 2006;28(6):881-892.

2. Richelson E, Souder T. Binding of antipsychotic drugs to human brain receptors focus on newer generation compounds. Life Sci 2000;68(1):29-39.

3. Vera PL, Miranda-Sousa A, Nadelhaft I. Effects of two atypical neuroleptics, olanzapine and risperidone, on the function of the urinary bladder and the external urethral sphincter in anesthetized rats. BMC Pharmacol 2001;1:4.

4. Soliman HM, Wagih HM, Attia GM, Algaidi SA. Light and electron microscopic study on the effect of antischizophrenic drugs on the structure of seminiferous tubules of adult male albino rats. Folia Histochem Cytobiol 2014;52(4):335-349.

5. Gulec M, Ozcan H, Oral E, et al. Nephrotoxic effects of chronically administered olanzapine and risperidone in male rats. Klin Psikofarmakol Bul Clin Psychopharmacol 2012;22(2):139.

6. Katzung BG. Histamine, serotonin and ergot alkaloids. In: Basic and Clinical Pharmacology. 13th ed. Mc Graw Hill; 2015:437-468.

7. Katzung BG. Cholinoceptor-Blocking drugs. In: Basic and Clinical Pharmacology. 13th ed. Mc Graw Hill; 2015:209-227.

8. Heiser P, Sommer O, Schmidt a J, et al. Effects of antipsychotics and vitamin $\mathrm{C}$ on the formation of reactive oxygen species. $\mathrm{J}$ Psychopharmacol 2010;24(10):1499-1504.

9. Halici Z, Keles ON, Unal D, et al. Chronically Administered Risperidone Did Not Change the Number of Hepatocytes in Rats: A Stereological and Histopathological Study. Basic Clin Pharmacol Toxicol 2008;102(5):426-432.

10. Shertzer HG, Kendig EL, Nasrallah HA, Johansson E, Genter MB. Protection from olanzapine-induced metabolic toxicity in mice by acetaminophen and tetrahydroindenoindole. Int $\mathrm{J}$ Obes 2010;34(6):970-979.

Copyright: ( $)$ the author(s), publisher. Academia Anatomica International is an Official Publication of "Society for Health Care \& Research Development". It is an open-access article distributed under the terms of the Creative Commons Attribution Non-Commercial License, which permits unrestricted non-commercial use, distribution, and reproduction in any medium, provided the original work is properly cited.

How to cite this article: Akram W, Syed M, Faruqi NA. Histopathological and Histomorphometric Studies on the Effects of Olanzapine on Vas Deferens and Urinary Bladder: An Experimental Study in Albino Rats. Acad. Anat. Int. 2019;5(1):100-103.

DOI: dx.doi.org/10.21276/aanat.2019.5.1.24

Source of Support: Nil, Conflict of Interest: None declared. 